\title{
DRYLAND LUCERNE FARMING
}

\author{
J. S. Paterson \\ Farmer, "Red Court," Gimmerburn, Ranfurly
}

\section{Introduction}

"RED Court" comprises 977 acres, of which 500 acres is very dry undulating-to-rolling country classified as Becks clay loam, probably some of the best soil in the district for dryland farming. There are 200 acres of Wetherburn soil on the high terraces. The Wetherburn soils are flat with a hard pan or "Maori bottom" about 20 in. below the surface. No moisture can be obtained from below, so lucerne on this country is dependent entirely on rainfall. There are 77 acres of creek channel and swamp and 200 acres of medium-to-light flats known as Ranfurly soils; these are good soils on the low terraces above the Wedderburn stream. They are suitable for hay production, and one cut each season could be expected in three seasons out of four.

Rainfall in the district varies from 10 to 19 in., with an average of 14 in. There appears to be nothing consistent about when it falls and a six-month period with only light rainfall is fairly consistent. On average, one out of four seasons is very dry, and in one of twelve seasons there is a bad drought. Thus, one good season, one average, and one very dry season can be expected in four.

Rain, and when it falls, are the governing factors in the growth of lucerne. If, at the end of winter, the subsoil is wet, a reasonable grazing season can be anticipated. If everything is dry, it is wise policy to prepare for a poor grazing season, to sell all unecessary stock, and conserve what growth there is for the fat lamb crop.

\section{Development with Lucerne}

In 1938, there were only 40 acres of lucerne, on the better-class land, and this was being used for a hay paddock. The remainder was in a run-out state with fescue, ryegrass, sorrel, dandelion and some Kentucky bluegrass. Soils were too depleted to hold grass pasture for any length of time and after dry conditions recovery was 
very slow. Many years before, wheat and oats had been grown and these had reduced any natural fertility to a low ebb.

Lucerne is established by ploughing in the autumn and discing down in the early spring. Cultivation consists of grubbing as often as necessary to suppress weed growth, and discing in spring and early summer to prepare the seedbed. A mixture of $8 \mathrm{lb}$ lucerne and 8 to $10 \mathrm{oz}$ of soft turnips is sown out in January or early February,, Should the ground be carrying heavy couch, it may be necessary to grow a green feed crop the first year and sow in lucerne and turnips the following year. Sowing with turnips does not appear to harm the young lucerne; in fact, the tramping and build-up in fertility as the turnips are eaten off appear to strengthen the lucerne in its early life. Natural fertility is high and no response has been obtained from fertilizers. Most varieties of lucerne have been tried. The New Zealand Certified has proved the most productive, and appears to grow better in dry periods. For preference, straight lucerne is sown and then ryegrass or cocksfoot over a portion of the block as an alternative feed. Lucerne-ryegrass and lucerne-cocksfoot mixtures have their place but lucerne does not thrive as well or last as long when sown in a mixture the less competition it has, the longer its life. Mixtures have become more popular in recent years, especially in an effort to combat barley grass, but in these circumstances the same production cannot be expected from lucerne.

On a straight diet of lucerne, the death rate of stock is higher than on a balanced mixture. A ratio of $70: 30$, i.e., 70 acres of lucerne to 30 acres of other grasses, appears a reasonably 'safe balance.

Once lucerne has been sown and established, the method of grazing it is most important. Some farmers have not been successful with grazing lucerne, possibly because of overgrazing for too long a period, especially in the young stages. There is no point in embarking on a lucernegrowing scheme unless one is prepared to graze the plant some distance off ground level for some of the growing season (though it may be necessary to punish paddocks, too, at times). At "Red Court", dry conditions have forced renewal of five blocks in the past 28 years because it was necessary to overgraze part of the farm during a drought. 
Usually, if there has to be some hard grazing during dry weather, one block is selected to take the punishment even if this means having to renew the lucerne. The main point to remember is that grazing should be like mowingeat off, and shift the sheep to another block.

Continuous heavy set-stocking, keeping the lucerne at ground level, will kill it out in one or two years. At some times of the year, there appears to be a waste of lucerne, but the result is a strengthening of the plants which is necessary for a long and successful grazing life. A previously depleted block, sown in March, 1939, has not been ploughed or sown since. Sowing in that year was late because of dry conditions and turnips were not included. An inspection of this stand today shows that it still supports two plants of lucerne per square foot. It has been mown about fourteen times, including three cuts in one season in 1943; three crops of seed have been harvested, but no mowing has been carried out during the last six years. A nother paddock was sown in January, 1943, with $8 \mathrm{lb}$ lucerne and $10 \mathrm{oz}$ Green Globe turnips. The turnips were a reasonably good crop and the 60 acres wintered 3,000 sheep. The lucerne was not expected to be successful because of the tramping and pugging it was subjected to, but, three weeks after the sheep were removed, it was up and green. Kentucky bluegrass is gradually covering the ground but this has been one of the best grazing blocks and still supports an average of two plants per square foot. Hay has been cut only once from a portion of the paddock.

In 1938, there were 600 halfbred ewes producing store lambs on the property. By 1950-1, full capacity had been reached at 1,100 ewes producing fat lambs. With the advent of lucerne, all lambs were drafted fat off the mothers and fattened on lucerne. In good seasons, lambs could be weaned and held on the lucerne blocks. This was particularly profitable when there was a premium on heavier lambs. In dry seasons, lambs still graded well at light weights,

At this stage, $70 \%$ of the farm or nearly 700 acres was in lucerne. The practice was to winter ewes on hay with some soft turnips when these were available. The ewes were lambed round the lucerne block and the manage ment varied according to the season. If possible, some 
paddocks were closed for hay, but in a dry spring all lucerne would be grazed and it was not possible to cut hay.

In 1950, a 700-acre block of tussock hill country was acquired where the ewes were summer-grazed after, January. The flock was increased to 1,500 ewes and better treatment for both ewes and lucerne was possible.

Advantages and Disadvantages of Lucerne

Lucerne is a plant which, if treated reasonably, grows longer in dry periods and recovers more quickly after rain than other species. From a stockman's point of view, one mouthful of lucerne appears to be better than two of anything else. Lucerne does a wonderful job of building up soil fertility and there are further advantages in low cost of establishment. In combination with turnips, it provides a valuable winter feed in the first year. However, it may have disadvantages also.

Losses can occur in breeding ewes because of bloat. Unless lucerne has grasses established with it, a longer dormant period is experienced during winter. This necessitates a little more winter feeding, usually at the beginning of winter. Lucerne is more susceptible to frost damage both late and early. Losses of grazing from frost damage can be considerable in the early spring and also in the autumn, particularly in areas heavily stocked with sheep. If a block has severe frost damage, it is better to have it eaten off and let it start a fresh growth. Frost damage appears to be worse when conditions are dry. Lush soft green lucerne does not appear to frost as easily. Heavy frost damage in early autumn can make winter feeding necessary a month earlier and lucerne is a risky proposition for fattening lambs in the autumn because of frost.

Wear on sheep's teeth is a most important factor when close grazing topsoil is loosened by the action of sheep's feet and becomes susceptible to erosion by wind or heavy rain. Even in calm weather, dust will rise from a paddock being grazed and settle on the lucerne. This may cause death of stock, particularly lambs. In a dry season, even young sheep, 2-, 4- and 6-tooths, can have their teeth worn to the gums by the abrasion of dusty feed. Heavy culling may be necessary following a dry season as there is the 
chance that two consecutive bad seasons could leave the flock with a high proportion of gummy sheep.

Barley grass can also be a problem because it establishes readily on the bare ground between lucerne plants. Good ground cover with competition from other grasses appears to be the answer to the barley grass problem in some areas but shallow-rooted pasture plants die out quickly when rainfall drops to as low as $10 \mathrm{in}$. Eat it, mow it, or live with it, appear to be the only economic answers to barley grass at present. It is a problem for only two to three months and does not justify spraying at $£ 310$ s. per acre on land carrying 1 to $1 \frac{1}{2}$ ewes.

\section{Provision of Stock W ater}

The provision of adequate stock water is a major problem, as it is in many parts of Central Otago. The flat and creek country is well supplied and when this dries up in the summer there are springs. The 700 acres of dry country, however, has no permanent stock water. Part of it has been watered by running a race from a creek and storing water in dams and natural lagoons. Some of these are up to $1.5 \mathrm{ft}$ deep and hold water during all of the summer period. Water keeps reasonably fresh in these lagoons provided they are big enough for the wind to circulate the water. Several attempts to bore for water have been unsuccessful. All that was achieved was to prove there is blue clay to a depth of at least $620 \mathrm{ft}$. Neighbouring farmers have struck good supplies of artesian water, often at depths not much more than $100 \mathrm{ft}$. Some are yielding 3,000 gallons of water an hour. Following failure with bores, $£ 1,200$ was spent on installing a $40 \mathrm{hp}$ electric pump and a concrete pipeline to pump two heads of water to the top of a hill from where it is conveyed by race to a series of dams and lagoons. This system can be operated only during the winter when there is ample water in the creek.

\section{Advances in Silage Making}

Two factors have been of particular importance in the lucerne programme described, first, the summer grazing facilities made available by the acquisition of the 700-acre hill country block, and, second, recent advancements in silage making. Once lucerne is established, surplus feed 
DRYLAND LUCERNE FARMING

can readily be converted into hay and silage. With the advent of vacuum silage, much shorter growth can be conserved for long periods without undue waste. In the years ahead, it seems certain that silage will play an ever increasing part in lucerne utilization.

\section{DISCUSSION}

$\mathrm{Mr}$ Beattie and Mr Paterson have put forward different views on including grasses in sowings of lucerne. Have their opinions altered after hearing each other's papers?

(BEATTIE): I still prefer to sow a grass-lucerne mixture because if the grass is sown in one block it runs out much more quickly than the lucerne and a depleted area is left in the paddock.

(PAterson): Lucerne and grass mixtures are satisfactory for grazing, but, on my country, they reduce production of the lucerne and shorten its life. The more grass, the less lucerne.

Would Mr Beattie and Mr Paterson comment on the possible effect on lambing percentages of grazing lucerne at tupping.

(BEATTIE): I have found no ill-effects. Lambing percentages bear out this statement as the percentage of lambs marked from 5-year-old ewes run with Southdown rams has' varied from $130 \%$ to the peak of $145 \%$ marked in 1966 (average, 135\%). At no time has grazing lucerne at tupping appear to have affected lambing percentages.

\section{What are your experiences of fattening lambs on lucerne?}

(BeAtTIE): Practically every lamb fattened on my property has been sent from a lucerne paddock. The number drafted ranges from 1,000 to 1,200 per year and weights are 30 to $32 \mathrm{lb}$. Care must be taken to draft downcross lambs early to avoid overfatness. I take the first draft of down lambs at 12 weeks.

(Paterson): In our low rainfall climate, I would say there is nothing better or more economic than lucerne. No cultivation is required, just stock management. However, frost can make it a little unreliable in the late autumn. 